\title{
OCHRONA

\section{PROBLEMATYKA OCHRONY HISTORYCZNEJ ZABUDOWY PRZEMYSŁOWEJ NA PRZYKŁADZIE ZESPOŁU PORTOWO-STOCZNIOWEGO GDYNI}

\section{HIRSCH Robert ${ }^{1}$, ŁOZOWSKA Celina $^{2}$}

${ }^{1}$ dr hab. inż. arch. Robert Hirsch, Wydział Architektury Politechniki Gdańskiej https://orcid.org/0000-0002-5427-3202

${ }^{2}$ mgr Celina Łozowska, Biuro Miejskiego Konserwatora Zabytków, Urząd Miasta Gdyni https://orcid.org/0000-0003-1058-0742

ABSTRAKT: Na terenach portowo-stoczniowych Gdyni zachowanych jest wiele historycznych obiektów, które ze względu na zmiany w funkcjonowaniu portu oraz przekształcenia użytkowania terenów podlegają określonym zmianom. Najważniejsze z tych budynków są objęte ścisłą ochroną prawną poprzez wpisanie do rejestru zabytków. Zapewnia to ich zachowanie i często także rewaloryzację. Inne, także wartościowe, ale nieobjęte tak ścisłą ochroną - uwzględnione tylko w ewidencjach zabytków, podlegają adaptacjom i przebudowom, które powodują utratę niektórych walorów, ale umożliwiają przynajmniej częściowe zachowanie. Wiele budynków tego typu utraciło swoje funkcje, jest opuszczonych i oczekuje na powtórne zagospodarowanie. Ochrona zabytków w takich sytuacjach jest bardzo problematyczna i wymaga wypracowania kompromisów. Przekształcenia budynków historycznych są nieuniknione. W celu określenia zakresu ochrony i dopuszczalności ingerencji pożądane jest wypracowanie metody oceny wartości zabytkowych, która dałaby narzędzia do zobiektywizowania procesów przekształceń.

SŁOWA KLUCZOWE: Gdynia, zabytki portowe, modernizm, wartościowanie 


\section{Wprowadzenie}

Dyskusja na temat zasad i granic przekształceń budynków zabytkowych jest szczególnie aktualna i ważna w odniesieniu do zabudowy przemysłowej, która w ciągu ostatnich kilkudziesięciu lat podlega wyjątkowo intensywnym przemianom mającym swoje źródło w procesach modernizacyjnych. Dobrym obszarem do analiz tego zagadnienia jest bardzo rozległy teren portowo-stoczniowy w Gdyni. Jest to obszar działalności gospodarczej związanej z morzem ukształtowany w latach 30 . XX wieku i rozwijany po II wojnie światowej. Obszar, na którym powstawała infrastruktura, w tym liczne budynki związane z transportem morskim, budową i remontami statków oraz rybołówstwem. Najstarszazabudowa historyczna na tym terenie pochodzi zkońcalat 20.XX wieku, ale wiele budynków późniejszych ma także istotne walory zabytkowe i unikatowe formy architektoniczne. W niniejszym artykule przedstawiono wybrane studia przypadków i na ich podstawie scharakteryzowano główne problemy związane ze współczesnym zagospodarowaniem tej części dziedzictwa.

\section{Ogólna charakterystyka}

Zespół portowo-stoczniowy, spójny pod względem zasadniczej funkcji jeszcze pod koniec $\mathrm{XX}$ wieku, przeszedł i nadal przechodzi znaczne przeobrażenia związane z przekształceniami praktycznie wszystkich zakładów przemysłowych. Zmiany te mają dwa zasadnicze kierunki. Pierwszy polega na kontynuacji działalności gospodarczej, ale podlegającej różnego rodzaju przemianom strukturalnym i modernizacyjnym. Dotyczy to dużych terenów portowych zarządzanych szczególnie przez Zarząd Morskiego Portu Gdynia. Prowadzona na nich działalność gospodarcza jest nieprzerwanie dostosowywana do wymogów rynkowych. Zmiany polegają też na tym, że w wyniku likwidacji dużych zakładów przemysłowych, jak np. Stocznia Gdynia zamknięta w 2009 roku, na ich terenach działają obecnie inne - mniejsze podmioty prowadzące bardzo różną działalność gospodarczą, także wymuszającą zmiany w zagospodarowaniu ${ }^{1}$.

Drugim kierunkiem przekształceń są trwałe zmiany funkcjonalne polegające na wyłączeniu obszarów przemysłowych z czynnej działalności gospodarczej i stopniowym ich włączaniu w przestrzeń miasta. Przykładem tego typu przestrzeni w Gdyni jest historyczne Molo Rybackie, czyli sztuczny pirs o wymiarach około 650 metrów na 200 metrów, służący przez lata intensywnej działalności związanej z rybołówstwem i przetwórstwem. Działalność prowadziło tu przedsiębiorstwo połowowe Dalmor, ale w tym miejscu została ona zakończona kilkanaście lat temu. Teren Mola Rybackiego został przeznaczony na funkcje usługowo-mieszkalne powiązane z sąsiednim śródmieściem, określone $\mathrm{w}$ specjalnie opracowanym miejscowym planie zagospodarowania przestrzennego ${ }^{2}$.

1 Teren dawnej Stoczni Gdynia objęty jest ustaleniami miejscowego planu zagospodarowania przestrzennego rejonu dawnej Stoczni Gdynia przyjętego uchwałą nr XXV/523/12 Rady Miasta Gdyni z dnia 28 listopada 2012 r., Dz. Urz. Woj. Pom. z 19 grudnia 2012 r., poz. 4452.

${ }^{2}$ Miejscowy plan zagospodarowania przestrzennego części dzielnicy Śródmieście w Gdyni rejonu Mola Rybackiego przyjęty uchwałą nr XXIV/505/12 Rady Miasta Gdyni z dnia 31 października 2012, Dz.Urz.Woj. Pom. z 6 grudnia 2012 r., poz. 3951. W efekcie analiz urbanistycznych i konserwatorskich zachowanej zabudowy Mola Rybackiego do zachowania i adaptacji wytypowano dwa historyczne obiekty - chłodnie rybne. Pozostałą część dawnej zabudowy poddano w dużej mierze rozbiórce, przygotowując teren pod nową zabudowę. 
Wskazane kierunki przekształceń wpływają także na istniejącą na tych obszarach wartościową zabudowę zabytkową, która jest narażona na istotne ingerencje. Ingerencje te podyktowane potrzebami użytkowymi dotykają budynków niezależnie od ich walorów i rodzaju ochrony konserwatorskiej.

Ochrona prawna zabytków na opisywanych terenach portowo-stoczniowych nie ma kompleksowego charakteru. Żaden większy obszar nie został wpisany do rejestru zabytków i tylko na części terenów obowiązują ustalenia miejscowych planów zagospodarowania przestrzennego. Sześć budynków historycznych zostało objętych indywidualnym wpisem do rejestru zabytków. W 1990 roku wpisano do rejestru Dworzec Morski, Elewator Zbożowy, Chłodnię Portową i Magazyn długoterminowy H, w 2007 roku zespół Łuszczarni Ryżu, a w 2016 roku Magazyn Tytoniowy ${ }^{3}$. Pozostałe historyczne obiekty zostały włączone do wojewódzkiej i gminnej ewidencji zabytków na przełomie 2010 i $2011 \mathrm{roku}^{4}$. Ochrona konserwatorska ogranicza się więc do pojedynczych nieruchomości. Wyjątkiem jest zespół Łuszczarni Ryżu, w przypadku którego wpis do rejestru obejmuje zespół kilku budynków.

Porównując ochronę zespołu portowo-stoczniowego z ochroną konserwatorską sąsiedniego śródmieścia Gdyni, które zajmuje porównywalną powierzchnię, można stwierdzić, że ochrona zespołu portowo-przemysłowego jest bardzo ograniczona i wybiórcza. Teren śródmieścia jako układ urbanistyczny został wpisany do rejestru zabytków i dodatkowo ponad 20 budynków na tym terenie jest wpisanych indywidualnie do rejestru ${ }^{5}$. Jednak w przeciwieństwie do śródmieścia obszar portowo-stoczniowy jest strefą intensywnej działalności biznesowej i ciągłych zmian, których kierunki są czasem nawet trudne do dokładnego określenia.

\section{Studia przypadków}

Dla kwestii definiowania zakresu ochrony i dopuszczalnych zmian w zabytkach interesujące wydaje się najpierw zapoznanie się z praktyką konserwatorską ostatnich lat i realnymi zmianami,

${ }^{3}$ Krótką charakterystykę każdego $\mathrm{z}$ wymienionych obiektów opisano w artykule: Orchowska-Smolińska A. Jaśkiewicz-Sojak A., Modernistyczna architektura przemysłowa i jej ochrona - na przykładzie portu gdyńskiego, [w:] M. J. Sołysik, R. Hirsch (red.), Modernizm w Europie - modernizm w Gdyni. Architektura lat międzywojennych i jej ochrona, Gdynia: Urząd Miasta Gdyni, 2009, ss. 231-242.

${ }^{4}$ W marcu 2010 roku nastąiła nowelizacja zapisów ustawy z dnia 23 lipca 2003 r. o ochronie zabytków i opiece nad zabytkami zmieniająca charakter prawny ewidencji zabytków. Na przełomie 2010/2011 roku Pomorski Wojewódzki Konserwator Zabytków ujął zabytkowe obiekty z terenu Gdyni w wojewódzkiej ewidencji zabytków. W listopadzie 2011 roku w aneksie do Programu Opieki nad Zabytkami Miasta Gdyni na lata 2011-2014 wprowadzono gminną ewidencję zabytków.

${ }^{5}$ Obszar śródmieścia wpisany został do rejestru zabytków w 2007 roku jako układ urbanistyczny, a w 2015 roku ustanowiono go Pomnikiem Historii. Teren ten jest w całości pokryty zapisami miejscowych planów zagospodarowania przestrzennego i jest obszarem o najwyższym priorytecie działan konserwatorskich. Instrumenty prawne, obok szczególnego czynnika, jakim jest trwałość funkcji historycznej (mieszkaniowo-usługowej), pozwalają na sformułowanie najbardziej właściwych zasad, dopuszczalnych form i granic interwencji/przekształceń obowiązujących w stosunku zabudowy śródmiejskiej. Zasady te w formie ogólnej zostały zawarte w MPZP, a szczegółowe rozwiązania stanowią przedmiot uzgodnień organów konserwatorskich. 
jakie zachodzą w obrębie historycznej zabudowy portowo-stoczniowej poprzez przedstawienie uproszczonych studiów przypadków. W celu dokonania przejrzystej charakterystyki problemów zachowane historyczne budynki na terenach przemysłowo-portowych Gdyni podzielono na trzy grupy według kryterium obecnego funkcjonowania i wynikających z tego zagadnień konserwatorskich. Grupę pierwszą stanowią budynki funkcjonujące nieprzerwanie zgodnie z pierwotnym przeznaczeniem. Do drugiej grupy należą budynki, których pierwotna funkcja wygasła i zostały poddane znaczącym przekształceniom i w pewnym sensie ich stan jest stały. Do trzeciej grupy należą budynki, które także przestały funkcjonować (albo to funkcjonowanie radykalnie ograniczono), ale nie zostały docelowo zagospodarowane, a niektóre $\mathrm{z}$ nich są zagrożone likwidacją.

Pierwszą grupę stanowią budynki, w których funkcja początkowa jest kontynuowana i które podlegają modernizacjom. Jednym z najbardziej ikonicznych budynków portu w Gdyni jest Elewator Zbożowy zlokalizowany na Nabrzeżu Indyjskim. Proces eksploatacyjny związany ze składowaniem i przeładunkiem ziarna jest w nim kontynuowany od czasu budowy w latach 1935-36. Budynek został wpisany do rejestru zabytków w 1990 roku (nr rej. 1306). Z uwagi na lokalizację w zamkniętej strefie jest widoczny dla przeciętnego odbiorcy praktycznie tylko od strony wody. W ciągu ostatnich kilkunastu lat nastąpiła dobudowa współczesnych silosów i urządzeń przemysłowych służących dalszemu funkcjonowaniu obiektu i kontynuacji działalności. Budynek rozbudowano w industrialnej formie charakterystycznej dla współczesnych inwestycji portowych, w małym stopniu ingerującej w strukturę zabytku, ale o kubaturze dobudowy dorównującej wielkości samego elewatora (Fot. 1). Ochrona konserwatorska sprawia jednak także, że prace remontowe przy samym budynku prowadzone są pod ścisłym nadzorem służb konserwatorskich ${ }^{6}$.

Kolejnym funkcjonującym nieprzerwanie budynkiem portowym jest Magazyn długoterminowy H (nr 5) przy ul. Polskiej 17, wpisany do rejestru zabytków w 1990 roku (nr rej. 1311). Budynek został zbudowany w dwóch etapach w latach 1931-34 i wyróżnia się widocznym w elewacjach żelbetowym szkieletem konstrukcyjnym z wypełnieniem z czerwonych cegieł. Pełni nadal funkcję magazynową, z pomieszczeniami na wynajem. Jest obecnie użytkowany ekstensywnie, a biorąc pod uwagę potrzeby współczesnego portu, nie jest optymalnie wykorzystany. Magazyn nie przeszedł istotnych przekształceń bryły, a z uwagi na ścisłą ochronę konserwatorską przeprowadzono w nim w ciągu ostatnich kilkunastu lat różne prace restauratorskie obejmujące m.in. elewacje ${ }^{7}$. Zachowane jest nawet wyposażenie wnętrz, np. windy towarowe, stalowe przesuwne kraty itp.

\footnotetext{
${ }^{6}$ Dotyczyło to np. prac przy elewacjach z okładzinami z płytek cementowych, które zostały w 2003 roku poddane pracom remontowym. Na skutek złego stanu zachowania okładziny zdecydowano o demontażu historycznych płytek cementowych i rezygnacji z ponownego licowania elewacji. W celu uzyskania podobnego efektu plastycznego wykonano wykończenie z szarego tynku o nacięciach imitujących pierwotny rysunek płytek.

7 Prace restauratorskie i remontowe zostały przeprowadzone na zamówienie użytkownika magazynu - Zarządu Morskiego Portu Gdynia.
} 


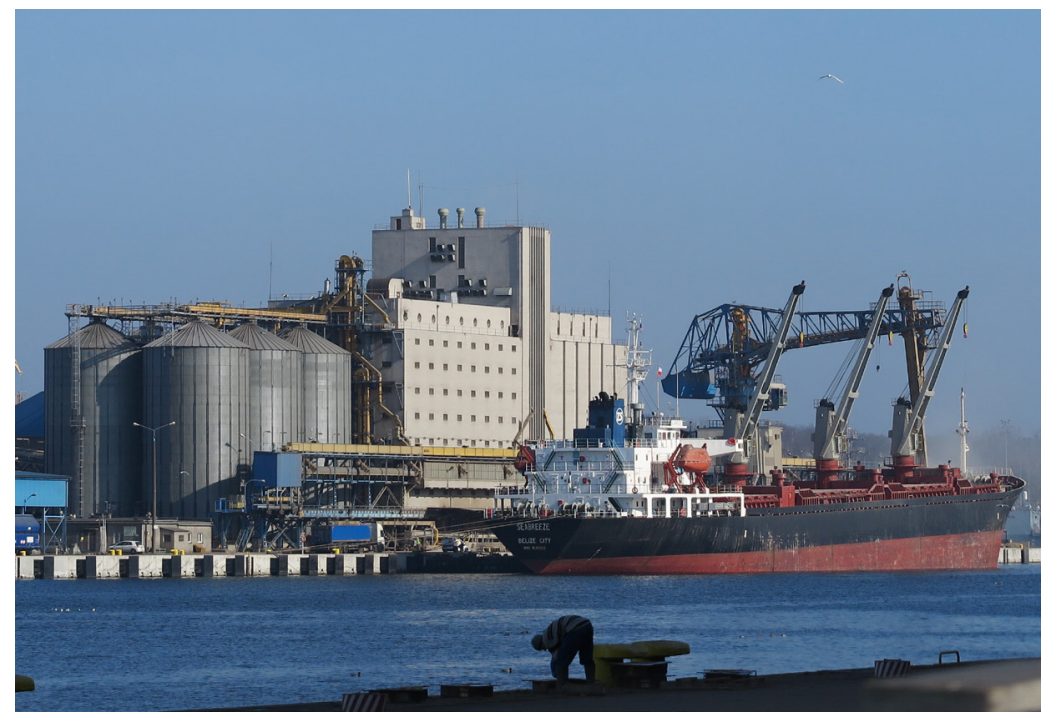

Fot. 1. Elewator Zbożowy z dobudowanymi silosami (z lewej strony), 2016 r., fot. R. Hirsch

Za inny przykład może służyć zespół Łuszczarni Ryżu przy ul. Indyjskiej 7/Celnej 2 zlokalizowany u nasady Nabrzeża Indyjskiego, czyli w zamkniętej strefie, niedostępnej dla osób postronnych. Zespół został wpisany do rejestru zabytków w 2010 roku (nr rej. 1805). Jest to jedna z pierwszych realizacji modernistycznych w porcie z lat 1927-28. Zespół składał się z budynku produkcyjnego, magazynu, budynku administracyjno-mieszkalnego, kotłowni z warsztatami, portierni, murowanego ogrodzenia. Procedura wpisu do rejestru zabytków była długotrwała ze względu na odwołania składane przez właściciela. Ostatecznie ochroną objęto trzy budynki zespołu, bez magazynu, który był w złym stanie technicznym. Magazyn został rozebrany, a w jego miejscu powstała nowa hala dostosowana do obecnych wymagań składowania, nawiązująca wystrojem (biało-czerwone pasy na elewacjach) do rozebranego

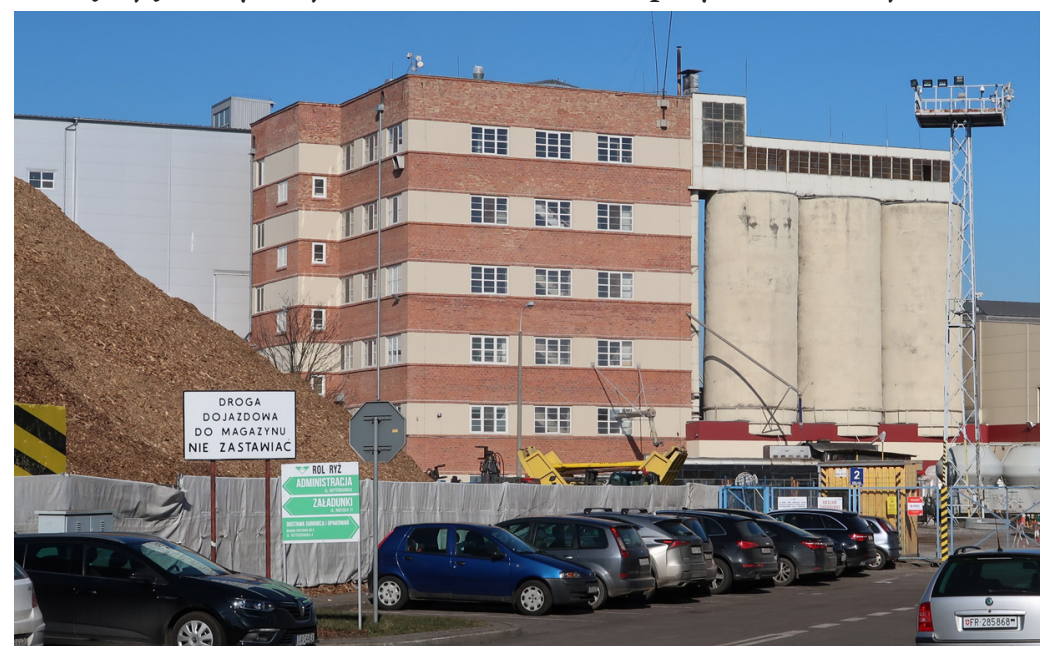

Fot. 2. Budynek produkcyjny Łuszczarni Ryżu z charakterystycznymi biało-czerwonymi pasami, z dobudowanymi współczesnymi silosami, 2021 r., fot. R. Hirsch 
obiektu. W obrębie zespołu Łuszczarni nastąpiła też dobudowa współczesnych, wysokich budynków, o przemysłowej formie, niezbędnych dla dalszej działalności produkcyjnej zespołu (Fot. 2). Pomimo industrialnego charakteru nowych budynków i niewątpliwego zakłócenia walorów ekspozycyjnych historycznych obiektów, historyczne bryły nie uległy istotnej ingerencji i pozostają wyraźnie czytelne. Dodać też należy, że zachowane trzy budynki poddano pracom konserwatorskim i są obecnie właściwie użytkowane.

$\mathrm{Z}$ analizy opisanych trzech przypadków można wyprowadzić następujące wnioski. Z uwagi na trwałą ochronę prawną wysokiej rangi poprzez wpisanie do rejestru wymienionych budynków nie jest kwestionowana konieczność ich zachowania. Dzięki temu budynki przeszły prace remontowe i restauratorskie. Z kolei dopuszczenie przekształceń w postaci częściowych rozbiórek oraz rozbudów, umożliwiło kontynuację przemysłowego funkcjonowania budynków. W związku z ciągłą eksploatacją przemysłową pewne ingerencje i modernizacje budynków dostosowujące je do współczesnych potrzeb, np. technologicznych, były niezbędne i nieuniknione. Z punktu widzenia ochrony zabytków uzyskano niewątpliwie dobre i trwałe efekty, także w postaci kontynuacji historycznych funkcji.

Drugą grupę stanowią budynki, których pierwotna funkcja wygasła i które zostały znacznie przekształcone. Jest to efekt obiektywnych procesów i zmian funkcjonalnych powodujących, że część przemysłowych terenów i historycznych budynków nieodwracalnie straciła swoje wcześniejsze użytkowanie. Jednym $\mathrm{z}$ takich obiektów jest budynek biurowo-magazynowy firmy „Bananas” zlokalizowany przy ul. Polskiej 22. Został zbudowany w latach $1938-39^{8}$ jako spójny obiekt stanowiący funkcjonalne połączenie dojrzewalni bananów z magazynami i częścią biurową. Charakterystycznym elementem budynku były jego czerwone, ceramiczne elewacje $\mathrm{z}$ dyskretnymi detalami. Kilkanaście lat temu obiekt został włączony do wojewódzkiej i gminnej ewidencji zabytków. Kilka lat później został jednak wyłączony z użytkowania i przewidziany przez właściciela do rozbiórki ze względu na przestarzałość. W miejscu tego budynku i sąsiedniego magazynu zaplanowano budowę nowoczesnego magazynu wysokiego składowania, czyli obiektu dostosowanego do współczesnych standardów portowych' . Wydana nawet została pozytywna opinia konserwatorska na temat rozbiórki ${ }^{10}$. W drodze podjętych rozmów i ustaleń wojewódzkiego konserwatora zabytków z właścicielem wypracowano kompromis polegający na dopuszczeniu częściowej rozbiórki obiektu i zgodzie na dobudowę współczesnego magazynu o rozmiarach znacznie większych od obiektu historycznego, zgodnie z potrzebami inwestora. Rewaloryzacji poddano pozostawioną od zachodu część biurową, a część północną rozebrano i odbudowano, dostosowując do współczesnych potrzeb (Fot. 3). Dzięki takiemu rozwiązaniu

\footnotetext{
${ }^{8}$ Orchowska-Smolińska A., Architektura i układ przestrzenny portu gdyńskiego lat międzywojennych jako dziedzictwo kulturowe, praca doktorska WA PG pod kierunkiem M.J. Sołtysik, mps, Gdańsk, 2013, s. 165.

9 Magazyny współczesne mają na ogół wysokie jednoprzestrzenne pomieszczenia składowe przystosowane do zmechanizowanej obsługi. Historyczne magazyny z okresu międzywojennego i powojenne miały liczne kondygnacje przystosowane do składowania i ręcznego przeładunku.

${ }^{10}$ Wojewódzki Konserwator Zabytków w Gdańsku wydał opinię pozytywną na temat rozbiórki kilku magazynów przy ul. Polskiej, w tym budynku firmy Bananas. Po zmianie na stanowisku WKZ w Gdańsku nowy WKZ Dariusz Chmielewski doprowadził do opisanego wyżej kompromisu.
} 


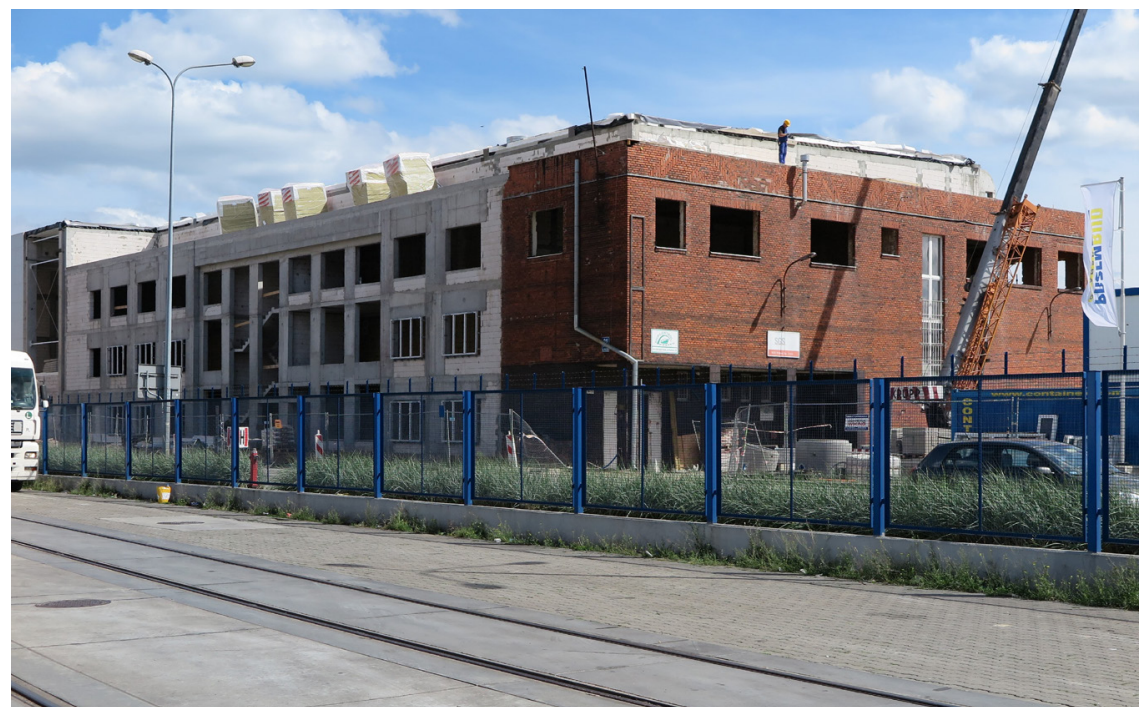

Fot. 3. Budynek firmy „Bananas” przy ul. Polskiej $21 \mathrm{w}$ trakcie remontu części zachodniej (część ceglana) i odbudowy części północnej (część z lewej strony), 2016 r., fot. R. Hirsch

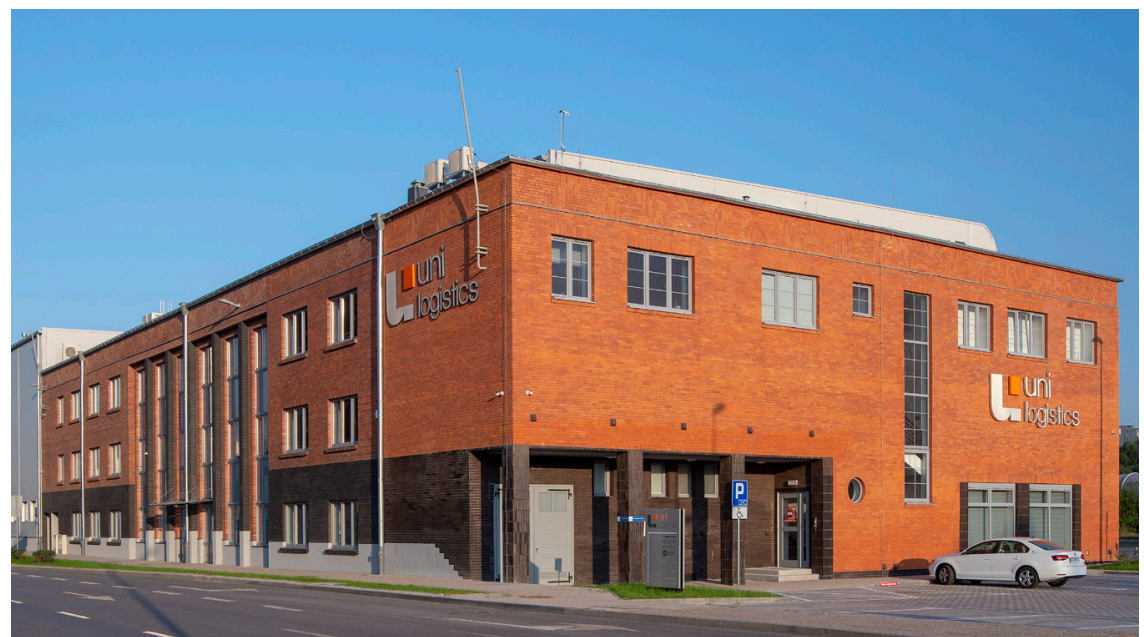

Fot. 4. Budynek firmy „Bananas” przy ul. Polskiej 21 po zakończeniu inwestycji i wybudowaniu magazynu wysokiego składowania (od tej strony widoczny jako białe pasmo nad ceglaną elewacją), 2017 r., fot. Urząd Miasta Gdyni

masywna bryła współczesnego magazynu z blaszanymi elewacjami jest na znacznej długości osłonięta przez części o historycznych formach (Fot. 4).

Innym przykładem, który wzbudził dużo kontrowersji i nadal wywołuje dyskusje, jest dawna Olejarnia „Union” przy ul. Indyjskiej 7. Zespół wzniesiony w 1930 roku i rozbudowany w latach $1932-33^{11}$ składał się z kilku części, a charakterystyczna fasada z napisami była najwyższym obiektem w porcie (Fot. 5). Na przełomie 2010 i 2011 roku Olejarnia została ujęta

${ }^{11}$ Sołtysik M. J., Gdynia miasto dwudziestolecia międzywojennego. Urbanistyka i architektura, Warszawa: Wydawnictwo Naukowe PWN, 1993, ss. 114-115. 


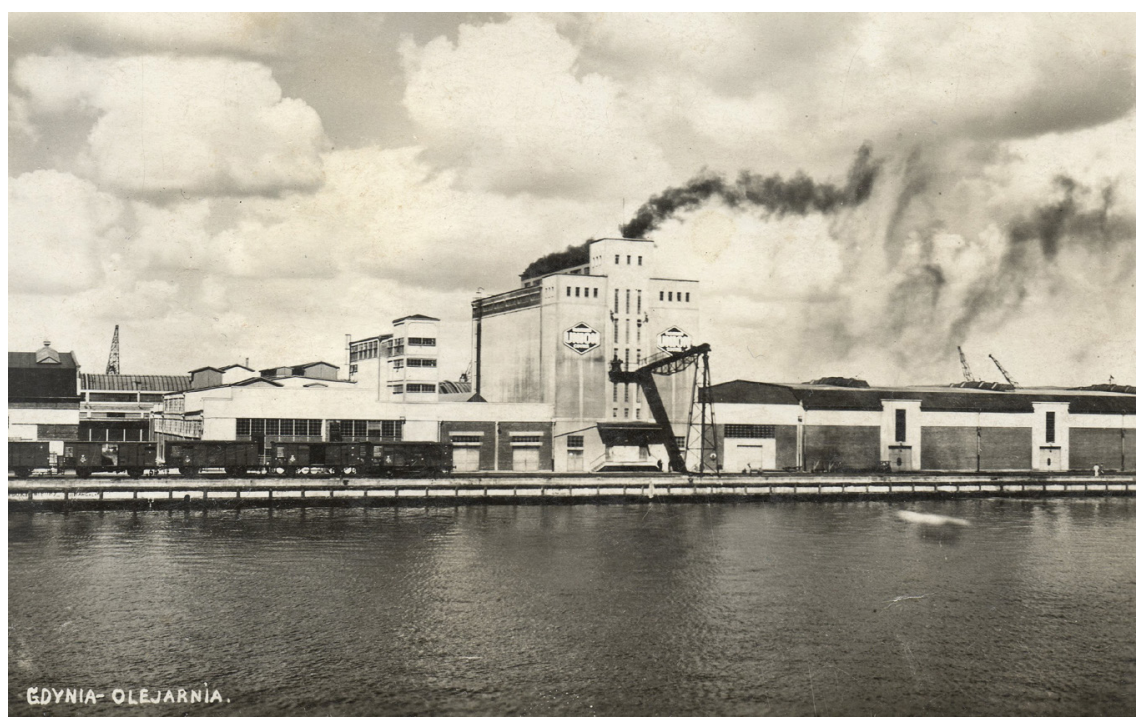

Fot. 5. Widok historyczny zespołu Olejarni w latach 30. XX w., fot. ze zbiorów prywatnych

w wojewódzkiej i gminnej ewidencji zabytków. W tym samym czasie zespół został wyłączony z użytkowania i zaplanowano na jego miejscu nową inwestycję przemysłową. Na skutek zbiegu różnych okoliczności, w tym m.in. błędów proceduralnych, rozpoczęta została rozbiórka całego zespołu Olejarni bez wymaganych uzgodnień konserwatorskich. W trakcie zaawansowanych prac rozbiórka została wstrzymana ${ }^{12}$. W wyniku kompromisu administracji budowlanej i konserwatorskiej z właścicielem zmieniono projekt inwestycji i zachowano charakterystyczną fasadę najwyższego budynku Olejarni. W kolejnym etapie inwestycji powstała hala o dużej kubaturze przeznaczona do montażu wielkogabarytowych konstrukcji stalowych. Nowa hala ma długość i wysokość znacznie większą niż dawna Olejarnia. Fasada Olejarni została zachowana i przylega do elewacji hali montażowej. Zestawienie tych dwóch obiektów ukazuje m.in. zmianę skali zabudowy portowej na przestrzeni lat (Fot. 6).

Ilustracją kompromisu pomiędzy ochroną konserwatorską zabudowy a nowymi inwestycjami, tym razem na terenach poprzemysłowych, zlokalizowanych w bezpośrednim sąsiedztwie śródmieścia, jest przypadek budynku firmy Hartwig. Ten niewielki budynek magazynowo-biurowy z lat 30. XX wieku położony jest przy ulicy Węglowej łączącej niegdyś miasto z portem. Obiekt stanowił relikt zabudowy przy tej ulicy, podkreślając swoją elewacją przebieg dawnego układu komunikacyjnego. Budynek miał bardzo prostą formę z charakterystycznym wykończeniem elewacji z pasmami $\mathrm{z}$ cegieł klinkierowych. Od końca lat 90 . XX wieku obiekt nie był już intensywnie użytkowany, a duża działka związana $\mathrm{z}$ budynkiem wykorzystywana była jako plac manewrowy i parking. Zgodnie z miejscowym planem zagospodarowania przestrzennego tereny wokół budynku zostały przeznaczone pod intensywną zabudowę mieszkaniową. Budynek historyczny swoim położeniem nieco skomplikował projekt nowego zespołu zabudowy. Na etapie uzgodnień dopuszczono zmianę

${ }^{12}$ Pozwolenie na rozbiórkę Olejarni wydał Wojewoda Pomorski, ale po stwierdzeniu uchybień, tj. braku uzgodnienia konserwatorskiego, decyzja została uchylona, a prace rozbiórkowe wstrzymano. 


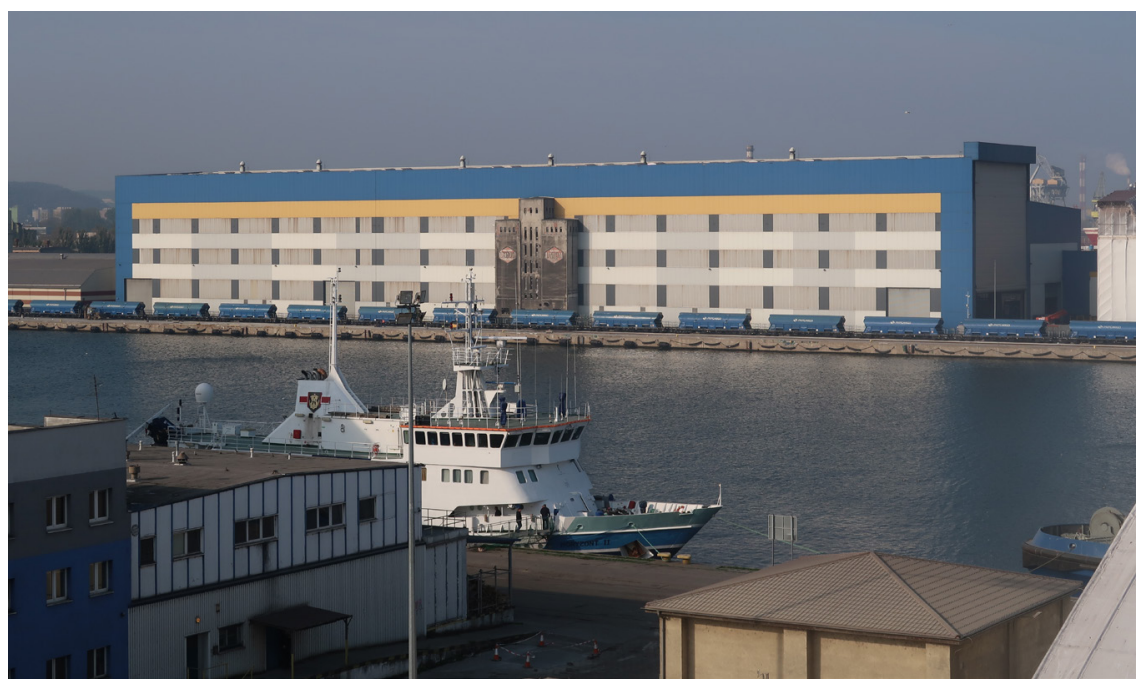

Fot. 6. Elewacja głównej części Olejarni z dobudowaną nową halą montażową, 2019 r., fot. R. Hirsch

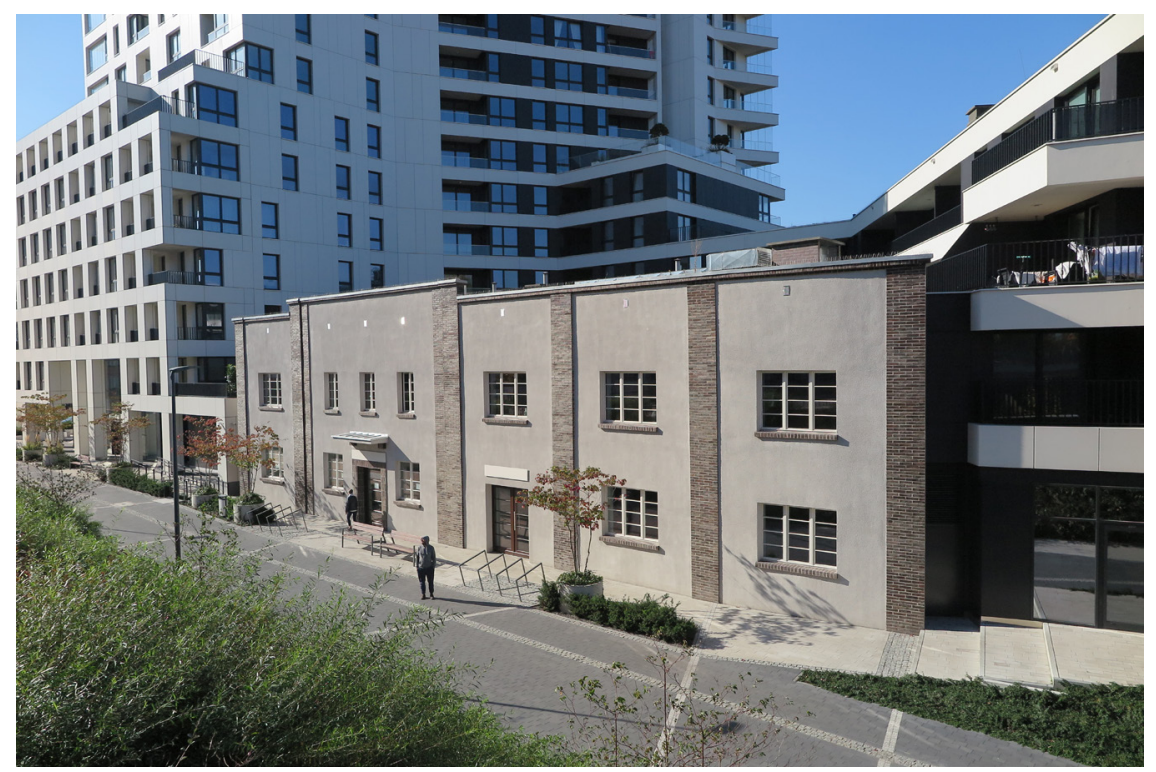

Fot. 7. Elewacje budynku firmy Hartwig przy ul. Węglowej 22 (niska część z pionowymi pasmami), pozostawione w strukturze nowej zabudowy mieszkaniowej przy ul. Węglowej, 2021 r., fot. K. Giełdon

konstrukcji i układu wnętrz budynku, ale zachowane miały być elewacje z detalami ceglanymi. W projekcie inwestycji budynek został wkomponowany w nową, wysoką zabudowę, którą tak ukształtowano, że budynek pozostaje wyraźnie wyodrębniony. Odrestaurowane zostały także 
historyczne elewacje budynku ${ }^{13}$ (Fot. 7).

Opisane powyżej przypadki pozwalają wysnuć następujące wnioski. W związku ze skalą przemian technologicznych i funkcjonalnych zachowanie budynków poprzemysłowych, które utraciły swoje pierwotne funkcje, jest trudne, zwłaszcza w sytuacji słabej ochrony konserwatorskiej takiej jak ewidencja zabytków. W wyniku braku ścisłej ochrony prawnej i ujęcia obiektów jedynie $\mathrm{w}$ ewidencji zabytków dopuszczalne formy interwencji i granice ingerencji są poddawane dyskusji i uznawane za uznaniowe ${ }^{14}$. W przypadku obiektów najcenniejszych $\mathrm{w}$ celu ich zachowania konieczne jest wpisanie do rejestru zabytków ${ }^{15}$. W innych przypadkach adaptacje i przystosowywanie do nowych funkcji są możliwe, ale wymagają czasem daleko idących kompromisów. Podane przykłady ukazują, że w każdym z przypadków z punktu widzenia zachowania dziedzictwa doszło do utraty znacznych jego elementów. $Z$ drugiej jednak strony zachowane zostały istotne i charakterystyczne elementy form historycznych - nośniki dziedzictwa, które włączono w obręb nowych inwestycji.

Trzecią grupę przykładów stanowią budynki historyczne, w których pierwotna funkcja bezpowrotnie wygasła i nie są użytkowane lub użytkuje się je ekstensywnie. Jedyną szansą na ich zachowanie w dłuższej perspektywie czasowej jest adaptacja. Procesy poszukiwania nowych funkcji i możliwości adaptacyjnych budynków poprzemysłowych trwają wiele lat i można wskazać w Gdyni kilka takich charakterystycznych przykładów.

Pierwszym przykładem są dwie dawne chłodnie rybne położone przy ul. Płażyńskiego na Molo Rybackim, będące pozostałością po przedsiębiorstwie połowowym Dalmor. Jedna znich zbudowana została w latach 1935-36 (I etap) i 1960-65 (II etap), a druga w latach 1948-52 $2^{16}$ (Fot. 8). Obiekty są ujęte w gminnej ewidencji zabytków i chronione zapisami obowiązującego na tym terenie miejscowego planu zagospodarowania przestrzennego. Teren Mola jest $\mathrm{w}$ praktyce wyłączony z działalności przemysłowej i przeznaczony został pod zabudowę mieszkalno-usługową. Budynki chłodni poza fragmentami powierzchni nie są użytkowane. Koncepcja włączenia tej części dawnego

${ }^{13}$ Nowa zabudowa działki wraz z wkomponowanym budynkiem historycznym otrzymała wyróżnienie w ogólnopolskim konkursie „Budowa Roku 2020” organizowanym przez Polski Związek Inżynierów i Techników Budownictwa przy współudziale Ministerstwa Inwestycji i Rozwoju oraz Głównego Urzędu Nadzoru Budowlanego. W części dawnego budynku magazynowo-biurowego Hartwig zaplanowano urządzenie przedszkola.

${ }^{14} \mathrm{O}$ konieczności poszukiwania kompromisów w procesie nowego zagospodarowania i adaptacji budynków, które utraciły historyczną funkcję pisali m.in.: Adamska Z., Kompleks przemysłowy z nowa funkcja - szansa na przetrwanie dziedzictwa czy zatarcie jego wartości?, [w:] Wartość funkcji w obiektach zabytkowych, B. Szmygin (red.), Warszawa: PKN ICOMOS, Muzeum Pałac w Wilanowie, Politechnika Lubelska, 2014, ss. 9-18; Zarębski L., Na czym polega skuteczna ochrona zabytków architektury o bezpowrotnie upadtej funkcji pierwotnej, [w:] B. Szmygin (red.), Ochrona wartości w procesie adaptacji zabytków, Warszawa: PKN ICOMOS, Muzeum Pałac w Wilanowie, Politechnika Lubelska, 2015, ss. 183-186.

${ }^{15}$ Taką decyzję podjęto w odniesieniu do Magazynu Tytoniowego przy ul. Polskiej 7, wpisanego do rejestru zabytków w 2016 roku.

${ }^{16}$ Historię gdyńskich chłodni portowych szczegółowo opisano w artykule: Orchowska-Smolińska A., Gdyńskie chłodnie portowe - studium przypadku przemystowej architektury portowej okresu modernizmu, [w:] M. J. Sołysik, R. Hirsch (red.), Modernizm w Europie - modernizm w Gdyni. Architektura XX wieku, jej ochrona i konserwacja w Gdyni i w Europie, Gdynia: Urząd Miasta Gdyni, 2018, ss. 85-94. 


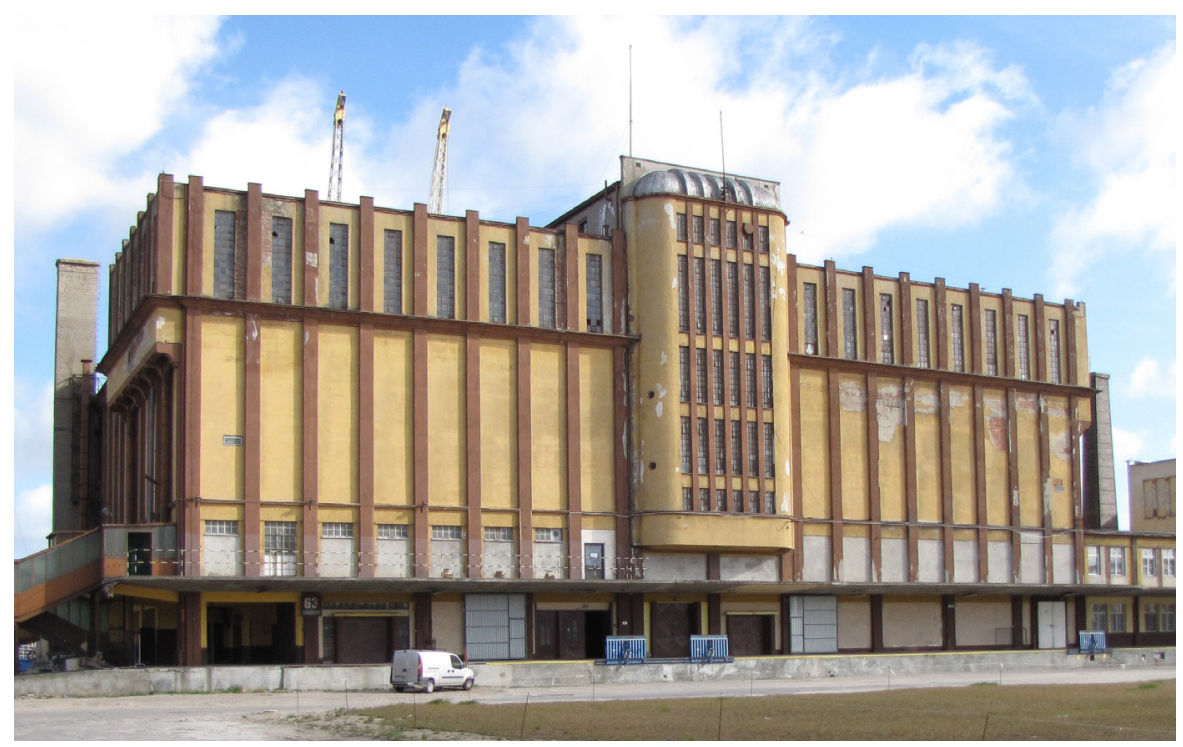

Fot. 8. Chłodnia rybna na Molo Rybackim oczekująca na adaptację, 2017 r., fot. R. Hirsch

portu w strukturę miasta i nowe zagospodarowanie terenu wiąże się jednak z poszukiwaniem nowej roli dla tych monumentalnych budynków poprzemysłowych o specyficznej architekturze. Utrudnienia w znalezieniu nowej funkcji wynikają z tego, że budynki nie mają doświetlenia wnętrz, kondygnacje są niskie i podzielone na komory i mają liczne podpory konstrukcyjne, co mocno komplikuje ich adaptacje. Nie została obecnie wybrana żadna nowa funkcja dla tych budynków i brak konkretnych planów adaptacji. Wykonane były koncepcje architektoniczne adaptacji na funkcje biurowe i wynikało $z$ nich, że konieczna byłaby m.in. istotna ingerencja w elewacje, tj. wykonanie okien, oraz modyfikacja układu wnętrz. Budynki położone są blisko centrum miasta i w ich przypadku adaptacja wydaje się realna, ale niewątpliwie będzie się wiązała ze znacznymi przekształceniami.

Podobne problemy dotyczą budynku dawnej elektrociepłowni Stoczni Gdynia zlokalizowanego przy ul. Czechosłowackiej 3, który jest włączony do ewidencji zabytków i chroniony zapisami miejscowego planu zagospodarowania przestrzennego. Budynek elektrociepłowni powstał w 1942 roku w ramach rozbudowy zakładu Deutsche Werke Kiel Gotenhafen, z kilkuetapową rozbudową od 1949 roku. Budynek o znacznej kubaturze i żelbetowej konstrukcji pozostaje od wielu lat wyłączony z eksploatacji. Stan techniczny budynku jest zły i wymaga kosztownego zabezpieczenia. Od wielu lat trwa poszukiwanie nowej funkcji m.in. poprzez organizowane specjalnie warsztaty architektoniczne ${ }^{17}$. W związku ze specyfiką architektury i lokalizacją (oddalenie od centrum miasta i sąsiedztwo budynków użytkowanych przemysłowo) znalezienie funkcji jest trudne, a brak zagospodarowania powoduje degradację budynku. Właściciele podejmowali próby

${ }^{17}$ W 2003 roku odbyly się specjalne warsztaty projektowe pod nazwą Gdynia Design Injection - w ramach programu Erasmus, w których wzięli udział studenci architektury z Gdańska, Nantes i Hamburga. Efektem były różne koncepcje adaptacji budynku, ale raczej mało realistyczne. 
wyłączenia budynku z ewidencji zabytków i doprowadzenia do rozbiórki, ale bez powodzenia. Szukając rozwiązania kompromisowego zamówili w ostatnim czasie opracowanie studialne wraz z wytycznymi konserwatorskimi ${ }^{18}$. Wytyczne nie określają jednak precyzyjnie warunków konserwatorskich, co w dużej mierze wynika ze zbyt dużej liczby nieznanych czynników.

W podobnej sytuacji jest jeszcze kilka budynków portowych w Gdyni, figurujących tylko w ewidencji zabytków. W związku z planowanymi działaniami inwestycyjnymi próbę usunięcia z wykazu ewidencyjnego podjęto również w przypadku budynku kotłowni B-117 oraz budynków warsztatowych B10A i B10B przy ul. Waszyngtona, zlokalizowanych na terenach dawnej Stoczni Nauta. Teren objęty jest $\mathrm{m}$. in.. planami budowy tzw. Portu Zewnętrznego, w wyniku czego kolejne historyczne budynki przemysłowe stoją bezpośrednio lub pośrednio $\mathrm{w}$ kolizji z zamierzeniami rozwojowymi. Ze względu na brak użytkowania i postępującą destrukcję właściciel terenu podejmuje działania, aby pozbawić budynki ochrony konserwatorskiej i je wyburzyć.

Budynki opisane powyżej są objęte ochroną konserwatorską przez włączenie do wojewódzkiej i gminnej ewidencji zabytków, a niektóre dodatkowo poprzez objęcie ochroną w zapisach miejscowych planów zagospodarowania przestrzennego. Wszystkie utraciły bezpowrotnie swoją funkcję i są dziś trudne do adaptacji, co wynika $\mathrm{z}$ ich specyfiki ${ }^{19}$. W praktyce trudno obecnie określić, jakie funkcje mogą w nich zostać umieszczone i w jakim horyzoncie czasowym.

\section{Podsumowanie}

Przedstawione przykłady pokazują praktyczne problemy ochrony zabudowy terenów portowostoczniowych Gdyni. Wnioski, jakie można sformułować na podstawie analizy wybranych przykładów, dotyczą oczywiście sytuacji lokalnej, ale wydaje się, że niektóre z nich mogą być bardziej uniwersalne.

Kluczowa dla pozycji wyjściowej budynku mającego podlegać przekształceniom jest jego ochrona prawna. W przypadku budynków wpisanych do rejestru zabytków nie podlega dyskusji konieczność ochrony i zachowania podstawowych walorów. W przypadku budynków objętych ochroną jedynie poprzez ujęcie w wojewódzkiej i gminnej ewidencji zabytków zasadność i zakres ochrony są często kwestionowane przez właścicieli, którzy zdają sobie sprawę ze słabości tego sposobu ochrony. Brakuje też przy tym praktycznych narzędzi prawno-administracyjnych do sprawowania właściwej ochrony konserwatorskiej. Nieco bardziej jednoznaczna jest sytuacja w przypadku ochrony ustalonej w miejscowym planie zagospodarowania przestrzennego, pod warunkiem dość precyzyjnych zapisów na temat zakresu ochrony.

\footnotetext{
${ }^{18}$ Barton-Piórkowska J., Dokumentacja konserwatorska budynku elektrociepłowni EC-II, Gdynia 2021, ul. Czechosłowacka 3, mps Gdynia (wykonana na zlecenie: Pomorskiej Specjalnej Strefy Ekonomicznej sp. z o.o. z siedzibą w Sopocie).

${ }^{19}$ Na ograniczenia adaptacyjne wynikające ze specyfiki architektury zespołów i obiektów poprzemysłowych zwracał uwagę m. in.: Molski P., Funkcja - atrybutem wartości i ochrony zabytku, [w:] B. Szmygin (red.) Wartość funkcji w obiektach zabytkowych, Warszawa: PKN ICOMOS, Muzeum Pałac w Wilanowie, Politechnika Lubelska, 2014, ss. 189-194.
} 
W przypadku każdego budynku istotna jest jak najbardziej wnikliwa ocena jego walorów zabytkowych i wynikającego z tego zakresu ochrony konserwatorskiej oraz jego nienaruszalnych cech i właściwości. Na podstawie przeanalizowanych przypadków można stwierdzić, że oceny zakresu ingerencji były dokonywane $\mathrm{w}$ toku procedur administracyjnych przez urzędników organów ochrony zabytków, którzy kierowali się własną oceną sytuacji i bazowali na swojej wiedzy i doświadczeniu, które były bardzo różne. Uwzględniano też uwarunkowania programowe planowanej nowej inwestycji. W przypadku budynków wpisanych do rejestru, które nadal funkcjonują, dopuszczano niezbędne rozbudowy o charakterze przemysłowym jako kontynuację funkcji historycznych. Ograniczeniu podlegały gabaryty i lokalizacja nowych części w stosunku do historycznych obiektów. W konsekwencji tego kontynuacja pierwotnych funkcji o charakterze przemysłowym pozwala na utrzymanie budynków w dobrym stanie.

W odniesieniu do budynków objętych ochroną jedynie poprzez ujęcie w ewidencji zabytków zakres ochrony i ingerencji podlegał indywidualnej ocenie. Na ostateczny kształt przedsięwzięcia wpływał szereg czynników związanych nie tylko z walorami obiektów, ale też ich lokalizacją, stanem technicznym i ,potencjałem adaptacyjnym”. Brak dostatecznych narzędzi ochrony konserwatorskiej w przypadku tej grupy budynków skłaniał do bardziej liberalnego podejścia do kwestii granic interwencji w te obiekty. W niektórych przypadkach zasady ochrony i zakres możliwych zmian zostały w ogólnym kształcie ustalone już na etapie sporządzania zapisów ochrony konserwatorskiej w miejscowych planach zagospodarowania przestrzennego. Na ogół ingerencje w zabytkową tkankę były bardzo znaczne, co pociągało za sobą istotną utratę walorów kulturowych. Z drugiej jednak strony pozostawione części historycznych budynków (bo na ogół taki był efekt) jako fragmenty dziedzictwa kulturowego stały się trwałymi elementami nowych realizacji $i^{20}$.

Jakie wnioski można wysunąć w odniesieniu do budynków zabytkowych zespołu portowostoczniowego, które utraciły funkcję i nie są użytkowane, a nawet niekiedy odpowiednio zabezpieczone? W wielu przypadkach nie ma obecnie możliwości określenia ich nowej funkcji i wynikającego z niej zakresu niezbędnych zmian. Nie można też przewidzieć, jaki będzie przypuszczalny czas realizacji inwestycji. Zależy to od wielu czynników takich m.in. jak sytuacja gospodarcza, lokalizacja, potencjał inwestycyjny, potrzeby lokalne itd. Jaka może być w takiej sytuacji rola specjalistów i organów ochrony zabytków? Nie ma wątpliwości, że nawet nie znając przyszłej funkcji adaptowanego budynku, można podjąć próbę określenia walorów zabytkowych budynku historycznego, czyli zidentyfikowania atrybutów wartości. Na tej podstawie można określić zakres nienaruszalności struktury zabytku i jego otoczenia. Można zastosować analizy opisane w różnych publikacjach, np. bazujące na metodyce UNESCO, którą po pewnych modyfikacjach można zastosować do waloryzacji zabytków przemysłowych o znaczeniu „nieglobalnym”, jak proponuje Waldemar Affelt ${ }^{21}$. Dostępny jest też szereg innych propozycji

${ }^{20}$ Dla pełnego obrazu stanu zabytkowej zabudowy terenów przemysłowych Gdyni warto dodać, że poważne zmiany dotyczą budynków, które są przestarzałe technologicznie. Na tym samym terenie jest wiele zabytkowych budynków administracyjnych z lat 30. XX wieku i późniejszych, które z powodzeniem pełnią swoje funkcje i są utrzymywane $\mathrm{w}$ dobrym stanie.

${ }^{21}$ Affelt W. J., O różnorodności form wyrazu kulturowego technofaktów i ich znaczeniu, [w:] B. Szmygin (red.), Ochrona wartości w procesie adaptacji zabytków, Warszawa, 2015, ss. 25-27. 
procedur i narzędzi oceny opartych na dokumentach międzynarodowych i krajowych ${ }^{22}$.

W sytuacji lokalnej ochrony zabytków i obiektów o walorach raczej regionalnych przydatna mogłaby być uproszczona metoda oceny polegająca np. na wypełnieniu zunifikowanego formularza oceny wartości, z konkretnymi pytaniami i być może skalą ocen - trochę podobnie do stosowanych powszechnie i określonych prawnie wzorów kart ewidencyjnych i adresowych zabytków ${ }^{23}$. Warto zauważyć, że w obowiązującym po nowelizacji Rozporządzenia MKiDN wzorze karty adresowej zabytku rubryka nr 8 ma tytuł „Historia, opis i wartości”, a więc przewidziano miejsce także na określenie walorów zabytku. Karta oceny wartości mogłaby być dedykowana różnym typom zabytków, w tym także zabytkom przemysłowym. Pożądane byłyby pomocnicze wytyczne/instrukcje dla autorów kart, które pozwoliłyby na skierowanie uwagi na konkretne wartości takie jak np. kontekst przestrzenny, powtarzalność rozwiązań, walory architektoniczne, unikatowość konstrukcji, autentyczność, integralność i inne. Nie ulega wątpliwości, że formularze - karty, sporządzane przez doświadczonych specjalistów $\mathrm{w}$ dziedzinie architektury i ochrony zabytków, byłyby jedynie pomocniczym narzędziem służącym waloryzacji i formułowaniu zasad dotyczących możliwych przekształceń budynków zabytkowych. Jak zwracano uwagę w publikacjach, objęcie obiektu ochroną konserwatorską nie jest równoznaczne z pełnym rozpoznaniem jego wartości, a karty ewidencyjne stanowią niekiedy jedyną i przy tym niewystarczającą dokumentację, na podstawie której służby konserwatorskie muszą podejmować decyzje dotyczące przyszłości zabytku ${ }^{24}$.

Z jednej strony przedstawiona analiza przypadków zabytków zespołu portowo-stoczniowego Gdyni wskazuje, że ustalanie granic ingerencji w historyczną strukturę budynków przemysłowych było każdorazowo indywidualnym procesem, w którym brano pod uwagę szereg zmiennych czynników,ściśle wynikających zuwarunkowańi trudnych do określenia zdużym wyprzedzeniem. $\mathrm{Z}$ drugiej jednak strony nie opracowano także jednolitej dokumentacji konserwatorskiej o charakterze analitycznym, wartościującej zabytek na etapie przedinwestycyjnym. Być może zaproponowana karta oceny wartości pozwoliłaby na lepszą ocenę sytuacji i bardziej zobiektywizowane podejście konserwatorskie.

\footnotetext{
${ }^{22}$ Np. procedury oceny oddziaływania procesów inwestycyjnych na dziedzictwo, tzw. Heritage Impact Assesment, które w konsekwencji pozwalają na poszukiwanie najbardziej zrównoważonych wariantów adaptacji zabytków, sposobu ich użytkowania i możliwych przekształceń, uzależnionych od wartości obiektów i intensywności potencjalnych zamierzeń inwestycyjnych. Wydaje się, że tego typu analizy mogą być najbardziej odpowiednie w przypadku obiektów poprzemysłowych, w których pierwotna funkcja wygasła i obecnie niewyjaśniony jest ich docelowy status użytkowy. Bolek, T., Ocena oddzialywania na dziedzictwo przemystowe w procesie inwestycyjnym: zarys procedury, Studia Ekonomiczne I Uniwersytet Ekonomiczny w Katowicach nr 177, 2014, ss. 21-39.

${ }^{23}$ Rozporządzenie Ministra Kultury i Dziedzictwa Narodowego z dnia 26 maja 2011 r. w sprawie prowadzenia rejestru zabytków, krajowej, wojewódzkiej i gminnej ewidencji zabytków oraz krajowego wykazu zabytków skradzionych lub wywiezionych za granicę niezgodnie z prawem, tekst jednolity Dz.U. z dnia 11 stycznia 2021 r., poz. 56.

${ }^{24}$ Szmygin B., Analiza obiektu zabytkowego jako element współczesnych funkcji użytkowych - metodologia światowego dziedzictwa, [w:] B. Szmygin (red.), Adaptacja obiektów zabytkowych do współczesnych funkcji użytkowych, Warszawa -Lublin: PKN ICOMOS, 2009, ss. 129-130.
} 


\section{Bibliografia}

Adamska Z, Kompleks przemysłowy z nowa funkcja - szansa na przetrwanie dziedzictwa czy zatarcie jego wartości?, [w:] Wartość funkcji w obiektach zabytkowych, B. Szmygin (red.),Warszawa: PKN ICOMOS, Muzeum Pałac w Wilanowie, Politechnika Lubelska, 2014, ss. 9-18.

Affelt W. J., O różnorodności form wyrazu kulturowego technofaktów i ich znaczeniu, [w:] B. Szmygin (red.), Ochrona wartości w procesie adaptacji zabytków, Warszawa, 2015, ss. 7-42.

Affelt W., Wartościowanie dziedzictwa techniki: rozpoznawanie, interpretacja, zachowanie, [w:] B. Szmygin (red.), Wartościowanie w ochronie i konserwacji zabytków, Warszawa-Lublin: PKN ICOMOS - Biuro Stołecznego Konserwatora Zabytków - Politechnika Lubelska, 2012.

Bolek T., Ocena oddzialywania na dziedzictwo przemystowe w procesie inwestycyjnym: zarys procedury, Studia Ekonomiczne / Uniwersytet Ekonomiczny w Katowicach nr 177, 2014, ss. 21-39.

Hirsch R., Transformacja Dworca Morskiego w Gdyni na Muzeum Emigracji, Ochrona Dziedzictwa Kulturowego nr 9, 2020, ss. 43-56.

Kołodziej J., Ochrona dziedzictwa przemysłowego w Polsce, Ochrona Zabytków nr 51/3 (202), 1998, ss. 203-209.

Karczmarczyk S., Rawicki Z., Zabytki post-przemysłowe. Współczesne uwarunkowania ich ochrony, Czasopismo Techniczne. Budownictwo, z. 9, 3009, s. 176.

Molski P., Funkcja - atrybutem wartości i ochrony zabytku, [w:] B. Szmygin (red.) Wartość funkcji w obiektach zabytkowych, Warszawa: PKN ICOMOS, Muzeum Pałac w Wilanowie, Politechnika Lubelska, 2014, ss. 189-194.

Ochrona wartości w procesie adaptacji zabytków, B. Szmygin (red.). Warszawa: PKN ICOMOS, Muzeum Pałacu Króla Jana III w Wilanowie, Politechnika Lubelska, 2015.

Orchowska-Smolińska A., Architektura $i$ układ przestrzenny portu gdyńskiego lat międzywojennych jako dziedzictwo kulturowe, praca doktorska WA PG pod kierunkiem M.J. Sołtysik, mps Gdańsk, 2013.

Orchowska-Smolińska A., Gdyńskie chłodnie portowe - studium przypadku przemysłowej architektury portowej okresu modernizmu, [w:] M. J. Sołysik, R. Hirsch (red.), Modernizm w Europie - modernizm w Gdyni, Architektura XX wieku, jej ochrona i konserwacja w Gdyni i w Europie. Gdynia: Urząd Miasta Gdyni, 2018.

Orchowska-Smolińska A. Jaśkiewicz-Sojak A., Modernistyczna architektura przemysłowa i jej ochrona - na przykładzie portu gdyńskiego, [w:] M.J. Sołysik, R. Hirsch (red.), Modernizm w Europie - modernizm w Gdyni. Architektura lat międzywojennych i jej ochrona, Gdynia: Urząd Miasta Gdyni, 2009, ss. 231-242.

Sołtysik M. J., Gdynia miasto dwudziestolecia międzywojennego, Urbanistyka $i$ architektura. Warszawa: Wydawnictwo Naukowe PWN, 1993. 
Szmygin B., Rekomendacja o Historycznym Krajobrazie Miejskim - wdrożenie zmiany paradygmatu w ochronie miast historycznych, Budownictwo i Architektura nr 12 (4), 2013, ss. 117-126.

Zakres i granice ingerencji konserwatorskiej $w$ adaptacji obiektów i zespołów poprzemystowych, A. Kępczyńska-Walczak (red.), Łódź: Politechnika Łódzka - Urząd Miasta Łodzi, 2012.

Zarębski L., Na czym polega skuteczna ochrona zabytków architektury o bezpowrotnie upadłej funkcji pierwotnej, [w:] B. Szmygin (red.), Ochrona wartości w procesie adaptacji zabytków, Warszawa: PKN ICOMOS, Muzeum Pałac w Wilanowie, Politechnika Lubelska, 2015, ss. 183-186. 